\title{
Pandemi Sürecinde EBA Platformuna Yönelik Sınıf Öğretmenlerinin ve Öğrencilerinin Görüşleri
}

\author{
Şafak ULUÇINAR SAĞIR ${ }^{1} \quad$ Elif DAL ${ }^{2}$
}

Gönderim Tarihi: 23.03.2021

Kabul Tarihi: 02.06 .2021

Öz: Tüm dünyayı etkileyen küresel salgın döneminde eğitim öğretim faaliyetlerinin devamlılığı uzaktan eğitim ile sağlanmaya çalışılmıştır. Ülkemizde daha önceden de var olan Eğitim Bilişim Ağı (EBA) uygulaması uzaktan eğitimin yürütüldüğü temel platform olmuştur. Bu araştırmanın amacı EBA uygulamalarını sınıf öğretmenlerinin ve ilkokul öğrencilerinin görüşleri doğrultusunda değerlendirmektir. Bu araştırma karma araştırma yöntemlerinden açımlayıcı sıralı desende yürütülen çalışmanın nicel boyutu tarama modelinde, nitel boyutu fenomonografik araştırma olarak tasarlanmıştır. Araştırma grubunu 263 sınıf öğretmeni ve 10 ilkokul öğrencisi oluşturmaktadır. Çalışmada Sönmez, Yıldırım ve Çetinkaya'nın (2020) geliştirdiği 18 maddelik açık uçlu sorulardan oluşan anket formu ve 12 soruluk yarı yapılandırılmış mülakat formu ile veriler toplanmıştır. Verilerin analizinde nicel veriler için SPSS 25 paket programı kullanılmış, nitel veriler betimsel analiz ile çözümlenmiştir. Araştırmada öğretmenlerin EBA'da ders süresini yeterli buldukları, içeriğin öğrenci seviyesine uygun olduğunu düşündüklerini fakat öğretimde EBA'nın tek başına yeterli olmadığı ve öğrencilerine ulaşmakta güçlük çektikleri bulunmuştur. Öğretmen görüşleri yaş, mesleki kıdem, okutulan sınıf düzeyi ve hizmet bölgesine göre farklılık göstermemektedir. Öğrenci görüşleri ise EBA'ya en çok telefondan erişim sağladıkları, EBA dışında ek kaynak kullandıkları, verilen ödevlerde zorlandıkları ve fiziksel etkinlikler bakımından EBA'yı yetersiz gördükleri yönündedir. EBA'nın öğrencilerin ve öğretmenlerin görüşleri ve ihtiyaçları dikkate alınarak iyileştirilmesi şeklinde önerilerde bulunulmuştur.

Anahtar Kelimeler: Eğitim Bilişim Ağı (EBA), Pandemi süreci, Sınıf öğretmeni, İlkokul öğrencileri

\section{Elementary School Teachers' and Students' Opinions on The EBA Platform In Pandemic Process}

\begin{abstract}
During the global epidemic that affected the whole world, the continuity of education and training activities was tried to be provided by distance education. The Education Information Network (EBA) application, which existed before in our country, has been the main platform where distance education is carried out. The aim of this study is to evaluate EBA applications in line with the opinions of elementary school teachers and students. This study was conducted in an exploratory sequential design, one of the mixed research methods, and its quantitative dimension is in the survey model, its qualitative dimension is a phenomonography. While the survey model was used in the quantitative part of the study, the phenemonograhy was used in the qualitative part. The research group consists of 263 elementary school teachers and 10 students. In the study, data were collected with a questionnaire form consisting of 18item open-ended questions developed by Sönmez, Yıldırım and Çetinkaya (2020) and a semi-structured interview form with 12 questions. SPSS 25 package program was used for quantitative data in the analysis of the data, and the qualitative data were analyzed by descriptive analysis. In the study, it was found that teachers think that the course time is sufficient in EBA, the content is appropriate to the student level, but EBA alone is not sufficient in teaching and they have difficulty in reaching their students. Teachers' views do not differ according to age, professional seniority, class level and service area. Students' opinions are that they mostly access EBA by phone, use resources other than EBA in lessons, have difficulties in assignments, and consider EBA inadequate in terms of physical activities. Suggestions have been made to improve the EBA by taking into account the opinions and needs of students and teachers.
\end{abstract}

Keywords: Education Information Network (EBA), pandemic process, elementary school teacher, elementary school students.

\footnotetext{
${ }^{1}$ Amasya Üniversitesi, Türkiye, safak.ulucinar@amasya.edu.tr, ORCID:0000-0003-3383-5330

${ }^{2}$ Amasya Üniversitesi, Türkiye, elif0527dal@gmail.com, ORCID: 0000-0003-2550-1613
} 


\section{Gíriş}

Yirmi birinci yüzyılda insanlık hızlı sanayileşmenin etkisi ile birçok konuda değişime ve gelişime uğramıştır. Bu gelişim ve değişim etkisini bilgiyi elde etme yöntemlerinde ve eğitimde göstermiş ve bu durum eğitimde teknoloji kullanımının artmasına sebep olmuştur (Alkan, 2011; Gömleksiz ve Deniz, 2019). Eğitimdeki teknoloji ile meydana gelen bu gelişim çoğu zaman pozitif yönlü olmuştur. Demirarslan ve Usluel'e (2005) göre gelişen dünyada hayatımızın içine giren teknolojide verimin elde edilmesi, öğretmenlerin bilgisayar yetkinliklerini arttırma çabasına bağlıdır. Öğretmenin teknoloji bilme isteği ve gayretinin beraberinde başarıyı getirdiğine inanılmıştır. Bu durum öğrenciler için de geçerlidir. Etkili ve verimli kullanılan teknoloji her iki grup için de olumlu katkılara sebep olmaktadır (Tutar, 2015). Eğitimde artan teknoloji kullanımı ile uzaktan eğitime rağbet artmıştır (Dündar ve Yeşilyurt,2020). Uzaktan eğitim tarihinin Cumhuriyetin ilk yıllarına kadar dayandığı bilinmektedir. Bu yıllarda farklı araçlarla sağlanan uzaktan eğitim süreci, 21. yüzyıldaki gelişmeler ile internet aracılığı ile sağlanmaya başlanmış olup ilerleyen zamanlarda daha da artması beklenmektedir (Bozkurt, 2017; Hobson ve Puruhito, 2018).

Karaman ve Aydoğmuş'a (2018) göre eğitim kitlelerin çağdaşlaşmasına ve gelişmesine destektir. Eğitimin hedefi gözlenmek istenen bilgi, beceri, tutum gibi özelliklerin kazanılmasını sağlamaktır. Eğitim teknolojilerinin hedefi de eğitimin hedefleri ile paralellik gösterir. Eğitim teknolojileri, eğitimin bu amacını gerçekleştirmek için insan, teknoloji imkânına uygun olarak eğitim kuramları eşgüdümünde yöntem teknikleri belirleyerek eğitim materyallerini amacına uygun ve verimli kullanımını sağlama gayretindedir. Eğitim teknolojisi eğitimin nitelik ve veriminin artmasına sebep olmaktadır. Eğitim teknolojilerinin hızla hayatımıza girmeye başlaması ile akıllı tahtalar, tabletler, projeksiyonlar vs. teknolojik materyaller de eğitime dâhil olmuştur. Fakat bunun devamında öğretim materyaline de ihtiyaç duyulmuştur. Bundan dolayı Milli Eğitim Bakanlı̆̆1 Eğitim Bilişim Ağı (EBA) hayata geçirilmiştir (Tüysüz ve Çümen, 2016). Son yıllarda eğitimde teknolojik alt yapıları ve ekonomik alt yapıları güçlendirilmeye yönelik planlamalar yapılmaya başlanmıştır. Bu stratejilere yönelik olarak başta FATİH (Fırsatları Arttırma ve Teknolojiyi İyileştirme Hareketi) Projesi ve bu proje ile bütünlemiş EBA projesi alt yapıları güçlendirilmeye çalışılmıştır (Dündar ve Yeşilyurt,2020). Bu planların yeterli derecede verimli olması için okul yönetimlerinin de bu stratejileri tam anlayışla idrak etmesi ve uygulayabilmesi önemlidir (Kılıç Çakmak ve diğerleri, 2016).

Bilim ve teknolojideki değişme ve gelişmeler her zaman yaşantımıza olumlu etki etmeyebilir. Bilginin yayılmasındaki hız, radyasyon, virüs, hastalık gibi olumsuzlukların da yayılmasında kendini gösterebilmektedir. Aralık 2019 sonlarına doğru Çin'in Wuhan kentinde bulaşıcı hızı yüksek olan ve öldürücü etkileri olan bir koronavirüs türü tüm dünyayı etkilemiştir. Devam eden süreçte 11 Mart 2020 tarihinde Dünya Sağlık Örgütü tarafından bu virüsün salgın halini alan "pandemi" olarak COVID-19'u tüm dünyaya duyurulmuştur. Bunların ardından UNESCO 27 Mart 2020 itibariyle tahmini 1,5 milyardan fazla öğrenci ve 63 milyon eğitimcinin 188 ülkede salgından etkilendiğini bildirmiştir (UNESCO, 2020). Küresel bir salgın halini alan koranavirüs insan sağlını etkilemesinin yanı sıra maddi ve manevi birçok sorunun da ortaya çıkmasına sebebiyet vermiştir (Üstün ve Özçiftçi, 2020). Dünyada yaşamın diğer alanlarında olduğu gibi öğrenci, eğitimci ve veli çerçevesinde salgın şartlarında eğitim faaliyetlerinin sürdürülmesine yönelik bir takım önlemler alınmıştır. Bu zorunlu şartlar teknolojinin hayatımızdaki önemini bir kez daha ortaya koymuştur.

Günümüzde pandemide eğitim problemiyle baş edebilmemiz için gerekli alt yapı eğitim teknolojileri geçmişimizdedir. Koronavirüs hayatımıza dâhil olduktan sonra ülkemizde MEB, 
uzaktan eğitimi Eğitim Bilişim Ağı (EBA) online platformu ve ulusal televizyon kanalı (TRT) ile devam ettirmeye başlamıştır. Hızlı bir şekilde MEB ve TRT işbirliği ile eğitim materyalleri hazırlanmış ve her yaş grubundan öğrencinin kullanımına sunulmuştur. Bu süreçte EBA ön plana çıkmıştır (Pala, Arslan ve Özdinç, 2017). 2011-2012 akademik yılında geliştirilen EBA, teknolojiyi bir amaç olmaktan çıkarıp araçsallaştırmak, süreç içerisinde öğrencinin bilgiyi yapılandırmasına imkân sağlamak için ve öğretmen ve öğrencinin süreçte eksiklerine gidermeyi amaçlanarak ortaya konulmuştur (Ayan, 2018). Bu platform öğrencilerin çevrimiçi olarak ulaşabildiği bir uygulama olup öğrenmenin sadece okullarda olmayacağını her an her yerde olabileceğini savunur nitelikte bir uygulamadır (Tınmaz, 2013). EBA platformunda uzaktan eğitim öğrencilerin okul düzeyine göre planlanmıştır. Farklı saatlerde ilkokul, ortaokul ve lise öğrencilerine televizyonda TRT-EBA kanallarından yapılan yayınların yanı sıra öğrenciler kendi okullarındaki sınıfları ile online olarak belirli saatlerde öğretmenleriyle dersler yapmaktadır. Covid-19 salgını döneminde halk sağlı̆̆ını koruma amaçlı önlemlerden biri olarak okullar kapatılmış, bazı istisnalar dışında (8. ve 12. sınıflar, ana sınıfları) uzaktan eğitim tüm kademelerde zorunlu olmuştur. Bu şekildeki uzaktan eğitime hızlı geçiş eğitim sistemi üyelerine ağır yükler yüklenmesine sebep olmuştur. Fakat çoğu öğretmen veya okul bu yeniliklere gerekli alt yapıya sahip olmadıkları için yetişmekte zorlanmıştır. TEDMEM raporunda, öğretmenlerin uzakta eğitimle ilgili bir eğitim verilmeden iş yüklerinin artması büyük sorunlar yaratmış ayrıca sosyo-ekonomik yetersizlikler ve öğrenci açısından yetersizliklerin eğitime olumsuz etkileri olduğu vurgulanmıştır (TEDMEM, 2020).

Eğitim Bilişim A $\breve{g}$ (EBA) platform ile verilen eğitimlerin öğrencilerin ve öğretmenlerin sosyal ve bilişsel gelişim ve etkileşimine bir takım etkiler bırakacağı düşünülmektedir. Uzaktan eğitim sürecinde EBA kullanımının bilişsel ve duyuşsal etkilerinin belirlenmesi, öğretim tasarımı ve materyal geliştirilmesinde gerekli önlemlerin alınması, eksiklerin giderilmesi ve yeniden düzenlemelerin yapılması bakımından önemli görülmektedir. Eğitim sistemindeki küçük yaş grubunu oluşturan ilkokul öğrencilerinin teknoloji kullanımı ve uzaktan eğitim sürecindeki deneyimlerinin, öğretmenler ve öğrencilerin bakış açısıyla değerlendirilmesi ilerleyen zamanlarda bu yaş grubu için geliştirilecek öğretim materyalleri ve uygulamalar açısından yol gösterici olacaktır. Bu çalışmada; dünyanın ortak problemi olan Covid-19 salgınında eğitim faaliyetlerinin uzaktan yürütülmesinde temel etkileşimli ortam olarak EBA kullanımının öğretmen ve öğrenci görüşlerine göre değerlendirilmesi amaçlanmıştır. EBA'nın salgın sürecinde öğrencilerin sosyal ilişkilerine yansımasını ve öğretmenlerin sürece yönelik görüşlerini incelemek amacıyla aşağıdaki problemlere cevap aranmıştır:

- Sınıf öğretmenlerinin EBA uygulamasını yeterli bulma düzeyi ve sürece dair görüşleri nelerdir?

- Sınıf öğretmenlerinin görüşleri yaş, mesleki kıdem, okutulan sınıf düzeyi ve hizmet bölgesine göre nasıl değişmektedir?

- Öğrencilerin EBA'ya erişim araçları ve sürece yönelik görüşleri nelerdir?

\section{YÖNTEM}

\section{Araştırma Deseni}

$\mathrm{Bu}$ araştırmada hem nitel hem nicel verilerin kullanıldığı karma yöntem kullanılmıştır. Karma yöntem içerisinde, önce nicel yöntem kullanılarak bulguların elde edildiği ve bunlardan da yola çıkarak nitelin planlandığı açımlayıcı sıralı desen kullanılmıştır (Mazlum ve Atalay, 2017). Nitel ve nicel çalışmaların yoğunluklarını eşit düzeyde bulunduran açımlayıcı desenin amacı nitel verileri kullanarak nicelden elde edilen bilgileri açıklığa kavuşturmaktır (Yıldırım ve Şimşek, 2018). 
Çalışmanın nicel kısmında betimsel tarama deseni kullanılmıştır. Betimsel tarama deseni, var olan durumların ve varlığını sürdüren olayları, müdahale etmeden ele alarak betimlenmesine yarayan bir desendir (Çepni, 2018). Çalışmanın nitel kısmında ise fenomonografik araştırma modeli kullanılmıştır. Fenomonografik araştırma, farklı insanların bir fenomeni anlama ve algılama yollarını tanımlamayı amaçlar (Marton, 1986).

\section{Çalışma Grubu}

Çalışmanın evrenini 2020-2021 eğitim öğretim yılında farklı şehirlerde bulunan EBA'yı derslerinde kullanan öğretmenler ve onların öğrencileri oluşturmaktadır. Araştırmada örneklem seçimi iki aşamada yürütülmüştür. Çalışmanın nicel kısmında kolay ulaşılabilir örneklem seçim yöntemi ile gönderilen e-anket formlarına dönüt veren 263 öğretmen ile çalışılmıştır. Çalışmanın nitel kısmı için nicel kısımda yer alan öğretmelerin sınıflarındaki öğrenciler arasından seçilen, farklı ilkokullardan 10 öğrenci ile görüşmeler yapılmıştır. Nitel kısımda amaçlı örneklem seçim yöntemlerinden maksimum çeşitlilik örneklem yöntemi kullanılmıştır (Çepni, 2018). Patton'a (1987) göre amaçlı örneklem seçimi genelleme yapmaktan ziyade bir konuyu ayrıntılı araştırmayı gerektirir. Amaçlı örneklem çeşitlerinden olan maksimum örneklem çeşidinde ise amaç genelleme yapabilmek için farklılıklara odaklanmak yerine farklı durumlar arasındaki ortak noktalara odaklanmaktır (Yıldırım ve Şimşek, 2018). Tablo 1'de araştırmaya katılan sınıf öğretmenlerinin demografik özellikleri verilmiştir.

Tablo 1. Çalışmaya Katılan Sınıf Öğretmenlerinin Demografik Bilgileri

\begin{tabular}{|c|c|c|}
\hline Yaş & $\mathbf{n}$ & $\%$ \\
\hline $22-30$ & 89 & 33,8 \\
\hline $31-40$ & 66 & 25,1 \\
\hline $41-50$ & 82 & 31,2 \\
\hline 41 ve üzeri & 26 & 9,9 \\
\hline \multicolumn{3}{|c|}{ Mesleki Kıdem } \\
\hline $1-5 Y_{11}$ & 76 & 28,9 \\
\hline $5-12 Y_{11}$ & 51 & 19,4 \\
\hline $13-20 Y_{11}$ & 66 & 25,1 \\
\hline 21-40 Y1l & 69 & 26,2 \\
\hline $41+Y_{11}$ & 1 & 0,4 \\
\hline \multicolumn{3}{|c|}{ Hizmet Bölgesi } \\
\hline 1.Bölge & 202 & 76,8 \\
\hline 2.Bölge & 40 & 15,2 \\
\hline 3.Bölge & 21 & 8,0 \\
\hline \multicolumn{3}{|c|}{ Okutulan Sınıf Seviyesi } \\
\hline 1.Sinif & 118 & 44,9 \\
\hline 2. Sinif & 55 & 20,9 \\
\hline 3. Sinif & 55 & 20,9 \\
\hline 4. Sinif & 35 & 13,3 \\
\hline Toplam & 263 & 100,0 \\
\hline
\end{tabular}


Tablo 1 incelendiğinde çalışmaya katılan sınıf öğretmenlerinin çoğunun; yaş aralıklarının 22-30 yaş arası $(\% 33,8)$, mesleki kıdemlerinin 1-5 yıl arası (\%28,9), hizmet bölgelerinin çoğunluklu olarak $(\% 76,8)$ 1. bölgede ve öğretmenlerin bulundukları sınıf seviyesinin genel olarak 1 . sinıf $(\% 44,9)$ olduğu görülmüştür.

Çalışmaya katılan ilkokul öğrencilerinin demografik bilgisi Tablo 2' de verilmiştir.

Tablo 2. Katılımcı Öğrencilerin Demografik Bilgileri

\begin{tabular}{llll}
\hline Katılımcılar & Cinsiyet & Sinıf seviyesi & Okul türü \\
\hline Ö1 & K1z & 1 & Özel \\
Ö2 & Erkek & 1 & Devlet \\
Ö3 & K1z & 4 & Devlet \\
Ö4 & Erkek & 2 & Devlet \\
Ö5 & K1z & 1 & Devlet \\
Ö6 & K1z & 2 & Devlet \\
Ö7 & Erkek & 3 & Devlet \\
Ö8 & K1z & 4 & Devlet \\
Ö9 & K1z & 2 & Özel \\
Ö10 & Erkek & 1 & Devlet \\
\hline
\end{tabular}

Çalışmaya ilkokul birinci ve ikinci sınıftan üç, dördüncü sınıftan iki ve üçüncü sınıftan bir öğrenci katılmıştır. Bu altı kız, dört erkek öğrencinin ikisi özel okula sekizi de devlet okuluna devam etmektedir.

\section{Veri Toplama Aracı}

Karma yöntemin uygulandığı bu çalışmada nitel ve nicel veri toplama araçları kullanılmıştır. Araştırmanın nicel boyutunda 18 maddeden oluşan Sönmez, Yıldırım ve Çetinkaya (2020) tarafından geliştirilen anket formu kullanılmıştır. Anketi geliştiren araştırmacılar lisansüstü eğitim alan 4 sınıf öğretmeni ile sınıf eğitimi alanında uzmanlaşmış 2 akademisyenden yardım almışlardır. İlgili araştırmacıların izinleri e-posta ile alınarak uygulama yapılmıştır.

Araştırmanın nitel kısmının veri toplama aracı olarak yarı yapılandırılmış görüşme formu kullanılmıştır. Bu görüşme formları öğrencilere yüz yüze uygulanmıştır. Görüşme formu hazırlanırken alanyazın taranmış ve elde edilen bulgular doğrultusunda 12 sorudan oluşan bir görüşme formu oluşturulmuştur. Hazırlanan sorular hakkında akran görüşlerine başvurularak görüşmede sorulacak sorulara son şekli verilmiştir. Soruların açık ve anlaşılır olmasına dikkat edilmiştir. Görüşme formu kullanırken çok sık yapılan hatalardan olan çok kişiye ulaşmak gayreti yerine yeterli veri elde edilmeye çalışılmıştır (Creswell ve Clark,2018; Makatouni, 2002). Bu anlayıştan yola çıkarak 10 ilkokul öğrencisi ile görüşme yapılıştır. Çalışma bir öğrenciye pilot çalışma olarak uygulanmış ve giriş sorularına eklemeler yapılmıştır. Nitel çalışmada güvenirliği sağlamak amacıyla nicel yaklaşılmadaki gibi genellenebilirlik gayreti yerine ortak temalara varabilmek adına akranlara başvurulmuştur (Yıldırım ve Şimşek, 2018).

\section{Verilerin Toplanması}

Araştırmada kullanılacak veri toplama araçları belirlendikten sonra anket formu Google Form linki oluşturularak WhatsApp, Telegram, Bip gibi mesajlaşma uygulaması grupları üzerinden sınıf öğretmenlerine ulaştırılmıştır. Veriler 2020-2021 eğitim öğretim yılı güz dönemi sonunda altı haftada toplanmıştır. Nitel veriler için çocuklara yönelik olarak hazırlanan görüşme formları 8 
Ocak ile 12 Şubat tarihleri arasında katılımcı öğrencilere uygulanmıştır. Öğrencilerin yaşları dolayısı ile velilerden sözlü izinler alınmıştır. Veri kaybını engellemek için görüşmelerde velilere ve öğrencilerden onay alınarak ses kaydı yapılmıştır. Güvenirliği sağlamak adına yapılan görüşmelerden sonra transkript kayıtları öğrencilere ve velilere okutulmuş ve gerekli düzenlemeler yapılarak velilerin izinleri yazılı hale getirmek için imzaları alınmıştır.

\section{Verilerin Analizi}

Çalışmada anket ve yarı yapılandırılmış görüşme formundan elde edilen veriler ayrı analiz edilmiştir. Nicel kısımda Google Form üzerinden elde edilen bulgular SPSS 25 paket programı ile analiz edilmiştir. Betimsel istatistikler ve Ki Kare analizi yapılmıştır. Çalışmanın nitel kısmında kullanılan yarı yapılandırılmış görüşmelerden elde edilen veriler ise betimsel analiz yöntemi ile analiz edilmiştir (Yıldırım ve Şimşek,2018). Sonuçlar tabloda frekans ve yüzdelerle gösterilmiştir. Güvenirliği ve geçerliliği sağlamak için veri toplama süreci açıkça yazılmış, yapılan görüşmelerden doğrudan alıntılara yer verilmiştir (Çepni, 2018).

\section{BULGULAR}

"Sınıf öğretmenlerinin EBA uygulamasını yeterli bulma durumları nedir?" sorusuna yönelik olarak yapılan analizler farklı değişkenlere göre incelenmiştir. Öğretmenlerin ankete verdikleri cevaplar Tablo 3'de verilmiştir.

Tablo 3. Öğretmenlerin EBA Uygulamasını Yeterli Bulma Durumuna İlişkin Verilerin Analizi

\begin{tabular}{|c|c|c|c|}
\hline Tema & & $\mathrm{f}$ & $\%$ \\
\hline \multirow{4}{*}{ Ders süresini yeterliliği } & Evet & 211 & 80,2 \\
\hline & Kismen & 6 & 2,3 \\
\hline & Hayır & 46 & 17,5 \\
\hline & Toplam & 263 & 100,0 \\
\hline \multirow{4}{*}{ İçeriklerin öğrenci seviyelerine uygunluğu } & Evet & 188 & 71,5 \\
\hline & Kismen & 36 & 13,7 \\
\hline & Hayır & 39 & 14,8 \\
\hline & Toplam & 263 & 100 \\
\hline \multirow{4}{*}{ EBA derslerinin öğretim için tek başına yeterli } & Evet & 64 & 24,3 \\
\hline & Kismen & 16 & 6,1 \\
\hline & Hayır & 183 & 69,6 \\
\hline & Toplam & 263 & 100 \\
\hline
\end{tabular}

Tablo 3 incelendiğinde öğretmenlerin büyük çoğunluğunun EBA uygulamasını ders süresi ve içeriğin öğrenci seviyesine uygunluğu bakımından yeterli, öğretim için tek başına yetersiz bulduğu görülmektedir. Tablo 4'te uzaktan eğitim sürecine yönelik soruların betimsel analizi verilmiştir. 
Tablo 4. Uzaktan Eğitim Sürecine İlişkin Öğretmen Görüşleri

\begin{tabular}{|c|c|c|c|}
\hline Tema & & $\mathbf{f}$ & $\%$ \\
\hline \multirow{3}{*}{$\begin{array}{l}\text { Uzaktan eğitim döneminde öğrencilere ulaşmakta } \\
\text { zorlanma durumu }\end{array}$} & Evet & 159 & 60,5 \\
\hline & Bazen & 18 & 6,8 \\
\hline & Hayır & 84 & 31,9 \\
\hline \multirow{3}{*}{$\begin{array}{l}\text { Velilerinin mesleklerinin (eğitimlerinin) uzaktan } \\
\text { eğitim sürecini etkileme durumu }\end{array}$} & Etkiliyor & 224 & 85,2 \\
\hline & Kararsızım & 12 & 4,6 \\
\hline & Etkilemez & 27 & 10,3 \\
\hline \multirow{3}{*}{$\begin{array}{l}\text { Öğrencilerin çalışma ortamının uzaktan eğitime } \\
\text { uygunluğu }\end{array}$} & Uygun & 71 & 27,0 \\
\hline & Kismen uygun & 16 & 6,1 \\
\hline & Uygun değil & 176 & 66,9 \\
\hline \multirow{3}{*}{$\begin{array}{l}\text { Öğrencilerin ders kitapları dışında ek kaynaklardan } \\
\text { faydalanma durumu }\end{array}$} & Evet & 229 & 87,1 \\
\hline & Kararsızım & 7 & 2,7 \\
\hline & Hayır & 27 & 10,3 \\
\hline \multirow{12}{*}{$\begin{array}{l}\text { Öğgrencilerinize ek ödev ve görevlendirmede } \\
\text { başvurulan yollar/ iletişim kanalları }\end{array}$} & Telefon & 135 & 51,3 \\
\hline & Whatsapp & 50 & 19,0 \\
\hline & Zoom & 4 & 1,5 \\
\hline & Telefon ve EBA & 9 & 3,4 \\
\hline & Zoom, Telefon, EBA & 3 & 1,1 \\
\hline & Sosyal medya & 9 & 3,4 \\
\hline & $\begin{array}{l}\text { Telefon, sosyal } \\
\text { medya }\end{array}$ & 39 & 14,8 \\
\hline & $\begin{array}{l}\text { Kaynak Kitaplar ve } \\
\text { Sosyal Medya }\end{array}$ & 9 & 3,4 \\
\hline & Ek kitaplar & 1 & 0,4 \\
\hline & Okulistik, morpa & 1 & 0,4 \\
\hline & WhatsApp, Bip & 2 & 0,8 \\
\hline & Web 2 Araçları & 1 & 0,4 \\
\hline \multirow{8}{*}{$\begin{array}{l}\text { Uzaktan eğitim sürecinde aile içinde öğrenciye yardım } \\
\text { eden kişi / kişiler }\end{array}$} & Anne & 115 & 43,7 \\
\hline & Baba & 1 & 0,4 \\
\hline & Anne ve baba & 38 & 14,4 \\
\hline & Anne ve kardeşler & 36 & 16,1 \\
\hline & Büyük kardeşler & 18 & 6,8 \\
\hline & $\begin{array}{l}\text { Anne, baba ve } \\
\text { kardeşler }\end{array}$ & 43 & 16,3 \\
\hline & Aile yakınları & 5 & 1,9 \\
\hline & Hiç kimse & 1 & 0,4 \\
\hline
\end{tabular}

Öğretmenlerin büyük bir kısmı uzaktan eğitim sürecinde öğrencilere ulaşmakta zorlandığını, velilerin meslekleri dolayısıyla eğitimlerinin süreci etkilediğini, öğrencilerin çalışma ortamının uygun olmadığı ve öğrencilerin ders dışında ek kaynaklardan faydalandığını belirtmiştir. Öğretmenlerin öğrencilerine ek ödev ve görevlendirmeleri öğretmenlerin verdikleri cevaplarda tek başına teefon, tek başına Whatsapp veya Zoom diyenler olduğu gibi bazı cevaplar birden fazla aracı içermektedir. Çoğunlukla telefon ve WhatsApp uygulaması üzerinden ödevler verdikleri söylenebilir. Ailede en çok annenin öğrenciye yardımcı olduğu ağabey ve ablaların anneyle birlikte uzaktan eğitim sürecinde daha aktif olduğu Tablo 4'de görülmektedir. 
Tablo 5'te öğretmenlerin EBA uygulamasını yeterli bulma durumlarının yaşlara göre değişimi görülmektedir.

Tablo 5. EBA Uygulamasının Yeterli Bulma Durumlarının Yaş Grupları ile İlişkisi

\begin{tabular}{|c|c|c|c|c|c|c|}
\hline & & 22-30 yaş & $31-40$ yaş & 41-50 yaş & 51 ve üzeri & Toplam \\
\hline \multirow{4}{*}{ Ders süresini yeterliliği } & Evet & 61 & 59 & 69 & 22 & 211 \\
\hline & Kismen & 3 & 0 & 3 & 0 & 6 \\
\hline & Hayır & 25 & 7 & 10 & 4 & 46 \\
\hline & Toplam & 89 & 66 & 82 & 26 & 263 \\
\hline \multirow{4}{*}{$\begin{array}{l}\text { İçeriklerin öğrenci } \\
\text { seviyelerine uygunluğu }\end{array}$} & Evet & 57 & 52 & 57 & 22 & 188 \\
\hline & Kismen & 14 & 7 & 15 & 0 & 36 \\
\hline & Hayır & 18 & 7 & 10 & 4 & 39 \\
\hline & Toplam & 89 & 66 & 82 & 26 & 263 \\
\hline \multirow{4}{*}{$\begin{array}{l}\text { EBA Uygulamasının Tek } \\
\text { Başına Yeterli Bulunma } \\
\text { Durumu }\end{array}$} & Evet & 19 & 13 & 21 & 11 & 64 \\
\hline & Kismen & 5 & 5 & 5 & 1 & 16 \\
\hline & Hayir & 60 & 48 & 56 & 14 & 199 \\
\hline & Toplam & 89 & 66 & 82 & 26 & 263 \\
\hline \multirow{3}{*}{$\begin{array}{l}\text { Ek kaynak kullanma } \\
\text { durumu }\end{array}$} & Evet & 72 & 59 & 73 & 25 & 229 \\
\hline & Hayır & 17 & 7 & 9 & 1 & 34 \\
\hline & Toplam & 89 & 66 & 82 & 26 & 263 \\
\hline
\end{tabular}

Tablo 5'de öğretmenlerin ders süresini yeterli bulma durumları ile yaş gruplarının ilişkisi incelendiğinde, ders süresinin yeterli olduğu kanısı en fazla 41-50 yaş grubundaki öğretmenlerde iken en az 41 yaş ve üzeri yaş grubundadır. Buna karşın, ders süresinin yeterli olmadığı görüşü en fazla 22-30 yaş grubundaki öğretmenler tarafından ifade edilirken en az 51 yaş ve üzeri öğretmenler tarafından ifade edilmiştir. Yapılan Ki Kare analizi sonucunda bu ilişkinin anlamlı olduğu bulunmuştur, $\left[x^{2}(\mathrm{sd}=6, \mathrm{n}=263)=16,55, \mathrm{p}<0.05(\mathrm{p}=0,02)\right]$.

İçerikleri öğrenci seviyesine uygun bulma durumu ile yaş gruplarının ilişkisi incelendiğinde içeriği öğrenci seviyesine uygun olduğu kanısı en fazla 22-30 ve 41-50 yaş grubundaki öğretmenlerde iken en az 51 yaş ve üzeri yaş grubundadır. Buna karşın olarak öğrenci seviyesine uygun olmadığı görüşü genel olarak 22-30 yaş grubundaki öğretmenler tarafından ifade edilirken en az 51 yaş ve üzeri öğretmenler tarafından ifade edilmiştir. Yapılan Ki Kare analizi sonucunda bu ilişkinin anlamlı olmadığı bulunmuştur, $\left[x^{2}(\mathrm{sd}=6, \mathrm{n}=263)=10,34, \mathrm{p}>0.05(\mathrm{p}=0,11)\right]$.

EBA uygulamasını tek başına yeterli bulma durumu ile yaş gruplarının ilişkisi incelendiğinde EBA uygulamasının tek başına yeterli olduğu kanısı en fazla 41-50 yaş grubundaki öğretmenlerde iken en az 51 yaş ve üzeri grubundaki öğretmenlerdedir. Buna karşın EBA uygulamasının tek başsına yeterli olmadığı görüşü en fazla 22-30 yaş grubundaki öğretmenler tarafından ifade edilirken en az 51 yaş ve üzeri öğretmenler tarafından ifade edilmiştir. Yapılan Ki Kare analizi sonucunda bu

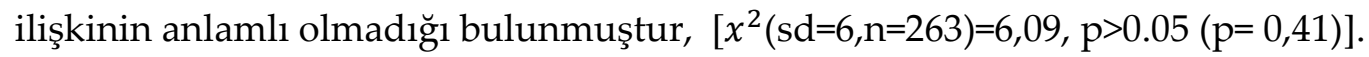

Ek kaynak kullanma durumu ile yaş gruplarının ilişkisi incelendiğinde ek kaynak kullandığını ifade edenlerin frekansı en fazla 41-50 yaş grubundaki öğretmenlerde iken en az 41 yaş ve üzeri yaş grubundadır. Buna karşın olarak ek kaynak kullanmadığını ifade eden öğretmenler genel olarak 22-30 yaş grubundaki öğretmenlerken 51 yaş ve üzeri öğretmenler tarafından en az frekansta ifade edilmiştir. Yapılan Ki Kare analizi sonucunda bu ilişkinin anlamlı olmadığ1 bulunmuştur, $\left[x^{2}(\mathrm{sd}=6, \mathrm{n}=263)=5,87, \mathrm{p}>0.05(\mathrm{p}=0,43)\right]$. Öğretmenlerin EBA uygulamasını yeterli bulma durumunun mesleki kıdemle değişimi Tablo 6 'da verilmiştir. 
Tablo 6. EBA Uygulamasının Yeterli Bulma Durumlarının Mesleki Kıdem ile İlişkisi

\begin{tabular}{|c|c|c|c|c|c|c|c|}
\hline & & $1-5 \mathrm{y} 1 \mathrm{l}$ & $5-12$ yıl & $13-20$ y1l & $21-40$ y1l & 41 yıl ve üzeri & Toplam \\
\hline \multirow{4}{*}{ Ders süresini yeterliliği } & Evet & 52 & 43 & 59 & 56 & 1 & 221 \\
\hline & Kismen & 2 & 1 & 1 & 2 & 0 & 6 \\
\hline & Hayır & 22 & 7 & 6 & 11 & 0 & 46 \\
\hline & Toplam & 76 & 51 & 66 & 69 & 1 & 263 \\
\hline \multirow{4}{*}{$\begin{array}{l}\text { İçeriklerin öğrenci } \\
\text { seviyelerine uygunluğu }\end{array}$} & Evet & 49 & 34 & 55 & 49 & 1 & 188 \\
\hline & Kismen & 13 & 6 & 6 & 11 & 0 & 36 \\
\hline & Hayır & 14 & 11 & 5 & 9 & 0 & 39 \\
\hline & Toplam & 76 & 51 & 66 & 69 & 1 & 263 \\
\hline \multirow{4}{*}{$\begin{array}{l}\text { EBA Uygulamasının Tek } \\
\text { Başına Yeterli Bulunma } \\
\text { Durumu }\end{array}$} & Evet & 15 & 9 & 20 & 19 & 1 & 64 \\
\hline & Kismen & 3 & 4 & 5 & 4 & 0 & 16 \\
\hline & Hayır & 58 & 38 & 41 & 46 & 0 & 183 \\
\hline & Toplam & 76 & 51 & 66 & 69 & 1 & 263 \\
\hline \multirow{3}{*}{$\begin{array}{l}\text { Ek kaynak kullanma } \\
\text { durumu }\end{array}$} & Evet & 60 & 46 & 55 & 67 & 1 & 229 \\
\hline & Hayır & 16 & 5 & 11 & 2 & 0 & 34 \\
\hline & Toplam & 76 & 51 & 66 & 69 & 1 & 263 \\
\hline
\end{tabular}

Tablo 6'da öğretmenlerin ders süresini yeterli bulma durumları ile mesleki kıdemlerinin ilişkisi incelendiğinde, ders süresinin yeterli olduğu kanısı en fazla 13-20 yıl aralığında kıdeme sahip öğretmenlerdedir. Buna karşın, ders süresinin yeterli olmadığ görüşü en fazla 1-5 yıl kıdeme sahip öğretmenler tarafından ifade edilmiştir. Yapılan Ki Kare analizi sonucunda bu ilişkinin anlamlı olmadığ bulunmuştur , $\left[x^{2}(\mathrm{sd}=8, \mathrm{n}=263)=11,59, \mathrm{p}>0.05(\mathrm{p}=0,17)\right]$.

Öğretmenlerin içerikleri öğrenci seviyesine uygun bulma durumu ile mesleki kıdemlerinin ilişkisi incelendiğinde içeriği öğrenci seviyesine uygun olduğu kanısı en fazla 13-20 yıl kıdeme sahip öğretmenlerdedir. Buna karşın olarak öğrenci seviyesine uygun olmadığ görüşü genel olarak 1-5 yıl kıdeme sahip öğretmenler tarafından ifade edilmiştir. Yapılan Ki Kare analizi sonucunda bu ilişkinin anlamlı olmadığ ${ }_{1}$ bulunmuştur $\left[x^{2}(\mathrm{sd}=8, \mathrm{n}=263)=9,16, \mathrm{p}>0.05(\mathrm{p}=0,32)\right]$.

Öğretmenlerin EBA uygulamasını tek başına yeterli bulma durumu ile mesleki kıdemlerinin ilişkisi incelendiğinde EBA uygulamasının tek başına yeterli olduğu kanısı en fazla 13-20 yıl kıdeme sahip öğretmenlerde iken en az 41 yıl ve üzeri kıdeme sahip öğretmenlerindedir. Buna karşın olarak EBA uygulamasının tek başına yeterli olmadığı görüşü en fazla 1-5 yıl kıdeme sahip öğretmenler tarafından ifade edilmiştir. Yapılan Ki Kare analizi sonucunda bu ilişkinin anlamlı olmadiğı bulunmuştur $\left[x^{2}(\mathrm{sd}=8, \mathrm{n}=263)=8,33, \mathrm{p}>0.05(\mathrm{p}=0,40)\right]$.

Öğretmenlerin ek kaynak kullanma durumu ile mesleki kıdemlerinin ilişkisi incelendiğinde ek kaynak kullandığını ifade edenlerin frekansı en fazla 21-40 yıl kıdeme sahip öğretmenlerdedir. Buna karşın olarak ek kaynak kullanmadığını ifade edenler en fazla 1-5 yıl kıdeme sahip öğretmenlerdir. Yapılan Ki Kare analizi sonucunda bu ilişkinin anlamlı olmadığı bulunmuştur [ $\left.x^{2}(\mathrm{sd}=8, \mathrm{n}=263)=14,45, \mathrm{p}>0.05 \quad(\mathrm{p}=0,07)\right]$. Öğretmenlerin okuttukları sınıf düzeyine göre EBA uygulamasını yeterli bulma durumları Tablo 7 'de verilmiştir. 
Tablo7. EBA Uygulamasının Yeterli Bulunma Durumu ile Okutulan Sınıf Seviyesinin İlişkisi

\begin{tabular}{llccccr}
\hline & & 1. sinıf & 2. sınıf & 3. sinıf & 4. sinıf & Toplam \\
\hline \multirow{4}{*}{ Ders süresini yeterliliğ̈i } & Evet & 88 & 48 & 46 & 29 & 211 \\
& Kismen & 3 & 2 & 1 & 0 & 6 \\
& Hayır & 27 & 5 & 8 & 6 & 46 \\
& Toplam & 118 & 55 & 55 & 35 & 263 \\
\hline \multirow{3}{*}{ İçeriklerin öğrenci } & Evet & 83 & 36 & 44 & 25 & 188 \\
seviyelerine uygunluğu & Kismen & 19 & 8 & 6 & 3 & 36 \\
& Hayır & 16 & 11 & 5 & 7 & 39 \\
& Toplam & 118 & 55 & 55 & 35 & 263 \\
\hline \multirow{2}{*}{ EBA Uygulamasının Tek } & Evet & 26 & 14 & 18 & 6 & 64 \\
Başına Yeterli Bulunma & Kismen & 7 & 3 & 3 & 3 & 16 \\
Durumu & Hayır & 85 & 38 & 34 & 26 & 183 \\
& Toplam & 118 & 55 & 55 & 35 & 263 \\
\hline \multirow{2}{*}{ Ek kaynak kullanma } & Evet & 98 & 51 & 50 & 30 & 229 \\
durumu & Hayır & 20 & 4 & 5 & 5 & 34 \\
\hline
\end{tabular}

Tablo7'de öğretmenlerin ders süresini yeterli bulma durumları ile okuttukları sınıf seviyesinin ilişkisi incelendiğinde, ders süresinin yeterli olduğu kanısı en fazla 1.sınıf öğretmenlerinde iken en az 4. sınıf öğretmenlerindedir. Buna karşın, ders süresinin yeterli olmadığ görüşü en fazla 1.sınıf öğretmenleri tarafından ifade edilirken en az 2.sınıf öğretmenleri tarafından ifade edilmiştir. Yapılan Ki Kare analizi sonucunda bu ilişkinin anlamlı olmadiğ bulunmuştur, $\left[x^{2}(\mathrm{sd}=6, \mathrm{n}=263)=6,70, \mathrm{p}>0.05(\mathrm{p}=0,34)\right]$.

İçerikleri öğrenci seviyesine uygun bulma durumu ile okutulan sınıf seviyesinin ilişkisi incelendiğinde içeriği öğrenci seviyesine uygun olduğu kanısı en fazla 1.sınıf öğretmenlerinde iken en az 4.sınıf öğretmenlerindedir. Buna karşın olarak öğrenci seviyesine uygun olmadığ görüşü genel olarak 1.sınıf öğretmenleri tarafından ifade edilirken en az 3.sınıf öğretmenleri tarafından ifade edilmiştir. Yapılan Ki Kare analizi sonucunda bu ilişkinin anlamlı olmadığ bulunmuştur, $\left[x^{2}(\mathrm{sd}=6, \mathrm{n}=263)=5,34, \mathrm{p}>0.05(\mathrm{p}=0,50)\right]$.

EBA uygulamasını tek başına yeterli bulma durumu ile okutulan sınıf seviyesinin ilişkisi incelendiğinde EBA uygulamasının tek başına yeterli olduğu kanısı en fazla 1.sınıf öğretmenlerinde iken en az 4.sınıf öğretmenlerindedir. Buna karşın olarak EBA uygulamasının tek başsına yeterli olmadığ1 görüşü genel olarak 1.sınıf öğretmenleri tarafından ifade edilirken en az 4.sınıf öğretmenleri tarafından ifade edilmiştir. Yapılan Ki Kare analizi sonucunda bu ilişkinin anlamlı olmadığ bulunmuştur, $\left[x^{2}(\mathrm{sd}=6, \mathrm{n}=263)=3,74, \mathrm{p}>0.05(\mathrm{p}=0,71)\right]$.

Ek kaynak kullanma durumu ile okutulan sınıf seviyesinin ilişkisi incelendiğinde ek kaynak kullandığını ifade edenlerin frekansı en fazla 1.sınıf öğretmenlerde iken en az 4.sınıf öğretmenlerindedir. Buna karşın olarak ek kaynak kullanmadığını ifade eden öğretmenler genel olarak 1.sınıf öğretmenleriyken en az 2.sınıf öğretmenleri tarafından ifade edilmiştir. Yapılan Ki Kare analizi sonucunda bu ilişkinin anlamlı olmadığ bulunmuştur $\left[x^{2}(\mathrm{sd}=6, \mathrm{n}=263)=7,17, \mathrm{p}>0.05\right.$ $(\mathrm{p}=0,30)]$.

Öğretmenlerin görev yaptıkları bölgeler Milli Eğitim Bakanlığının Şubat 2020'de yayınladı̆̆1 genelgeyle belirlenen hizmet bölgeleriyle uzaktan eğitim süreciyle ilgili görüşleri incelenmiş Tablo 8 'de verilmiştir. 
Tablo 8. Uzaktan Eğitim Sürecine İlişkin Görüşler ile Hizmet Bölgelerinin ilişkisi

\begin{tabular}{llllll}
\hline Tema & & 1.Bölge & 2.Bölge & 3.Bölge & Toplam \\
\hline Öğrenciye & Evet & 116 & 24 & 19 & 159 \\
ulaşmakta zorlanma & Bazen & 15 & 3 & 0 & 18 \\
& Hayır & 70 & 12 & 2 & 84 \\
& Toplam & 201 & 39 & 21 & 261 \\
\hline Öğrencilerinin & Uygun & 57 & 11 & 3 & 71 \\
Çalışma Ortamını & Uygun değil & 145 & 29 & 18 & 192 \\
Uygunluğu & Toplam & 202 & 40 & 21 & 263 \\
\hline Velilerin & Etkiliyor & 168 & 35 & 20 & 12 \\
mesleklerinin etkisi & Kararsizım & 11 & 1 & 0 & 27 \\
& Etkilemez & 23 & 4 & 1 & 263 \\
\hline
\end{tabular}

Tablo 8'de öğretmenlerin öğrenciye ulaşmakta zorlanma durumları ile görev yaptıkları hizmet bölgelerinin ilişkisi incelendiğinde, öğrencilerine ulaşmakta zorlandığını ifade eden görüş en fazla 1. Bölgede hizmet yapan öğretmenlerde iken en az 3. Bölgede görev yapan öğretmenlerdedir. Buna karşın ulaşmakta zorlanmadığını ifade eden görüş en fazla 1. Bölgede görev yapan öğretmenlerde iken en az 3. Bölgede görev yapan öğretmenlerdedir. Yapılan Ki Kare analizi sonucunda bu ilişkinin anlamlı olmadığ bulunmuştur $\left[x^{2}(s d=6, n=261)=8,74, p>0.05(p=0,06)\right]$.

Öğretmenlerin, öğrencilerinin çalışma ortamını uygun bulma durumu ile görev yaptıkları hizmet bölgelerinin ilişkisi incelendiğinde, öğrencilerinin çalışma ortamını uygun bulduğunu ifade eden görüş en fazla 1. Bölgede hizmet yapan öğretmenlerde iken en az 3. Bölgede görev yapan öğretmenlerdedir. Buna karşın öğrencilerinin çalışma ortamını uygun bulmadı̆̆ını ifade eden görüş en fazla 1. Bölgede görev yapan öğretmenlerde iken en az 3. Bölgede görev yapan öğretmenlerdedir. Yapılan Ki Kare analizi sonucunda bu ilişkinin anlamlı olmadığ bulunmuştur [ $\left.x^{2}(\mathrm{sd}=4, \mathrm{n}=263)=2,24, \mathrm{p}>0.05(\mathrm{p}=0,69)\right]$.

Öğretmenlerin, velilerin mesleklerinin dolayısıyla eğitimlerinin süreci etkisi ile görev yaptıkları hizmet bölgelerinin ilişkisi incelendiğinde, velilerin mesleklerinin süreci etkilediğini ifade eden görüş en fazla 1. Bölgede hizmet yapan öğretmenlerde iken en az 3. Bölgede görev yapan öğretmenlerdedir. Buna karşın velilerin mesleklerinin süreci etkilemediğini ifade eden görüş en fazla 1. Bölgede görev yapan öğretmenlerde iken en az 3. Bölgede görev yapan öğretmenlerdedir. Yapılan Ki Kare analizi sonucunda bu ilişkinin anlamlı olmadı̆̆ 1 bulunmuştur [ $\left.x^{2}(\mathrm{sd}=6, \mathrm{n}=263)=3,04, \mathrm{p}>0.05(\mathrm{p}=0,80)\right]$.

Çalışmaya katılan ilkokul öğrencilerine EBA'ya erişim araçları, web sitesine ulaşım durumları, yetersiz kaldığı durumlar, yararlandıkları ek kaynaklar gibi durumlara ilişkin sorulara verdikleri cevaplardan temalar belirlenmiş ve örneklerle Tablo 9'da gösterilmiştir. 
Tablo 9. İlkokul Öğrencilerinin EBA'ya İlişkin Görüşleri

\begin{tabular}{|c|c|c|c|}
\hline & Temalar & $\mathbf{N}$ & Örnek ifade \\
\hline \multirow{3}{*}{ EBA'ya erişim araçları } & Telefon & 7 & "Tabletten giriyorum."(Ç5) \\
\hline & Tabet & 2 & "Bilgisayar."(Ç9) \\
\hline & Bilgisayar & 1 & "Telefonla giriyorum."(Ç3) \\
\hline \multirow{3}{*}{$\begin{array}{l}\text { Katılımcıların } \\
\text { EBA Ders Web sitesine } \\
\text { ulaşmada zorlanma } \\
\text { durumları }\end{array}$} & Evet & 5 & "Birazcık zorlanıyorum. Orta."(Ç2) \\
\hline & & & "Ara sıra zorlanıyorum."(Ç3) \\
\hline & Hayır & 5 & "Hayır, zorlanmıyorum."(Ç8) \\
\hline \multirow{6}{*}{$\begin{array}{l}\text { EBA Dişında Kullanılan } \\
\text { Kaynaklar }\end{array}$} & Cisco Webex & 2 & "Evet, Webex ve Morpha'dan \\
\hline & Zoom & 2 & ulaşıyorum."(Ç1) \\
\hline & Bilmiyorum & 4 & “Zoom'dan ulaşıyorum."(Ç3) \\
\hline & Mesajlaşma Uygulamaları & 2 & "Bilmiyorum."(Ç6) \\
\hline & Morpha & 1 & "Evet, Berkay kaynağını..."(Ç8) \\
\hline & Ek Kaynak Kitap & 1 & “Cisco Webex'den..."(Ç9) \\
\hline \multirow{3}{*}{$\begin{array}{l}\text { EBA'nin Yetersiz Kaldı } \breve{g}_{1} \\
\text { Durumlar }\end{array}$} & Ders ile ilgili etkinlikler & 3 & Oyun oynama, koşma..."(Ç9) \\
\hline & Fiziksel etkinlikler & 7 & "Yani oyun oynama \\
\hline & Sözlü iletişim & 1 & $\begin{array}{l}\text { "Oyun oynamak, koşmak, } \\
\text { kovalamaca..."(Ç6) }\end{array}$ \\
\hline \multirow[b]{2}{*}{$\begin{array}{l}\text { EBA'da verilen } \\
\text { ödevlerde zorlanma } \\
\text { durumu }\end{array}$} & Evet & 6 & "Bazen zorlanıyorum onlarda zaten \\
\hline & Hayır & 4 & $\begin{array}{l}\text { annem ya da ablamdan yardım } \\
\text { alıyorum..."(Ç3) } \\
\text { "Biraz zorlanıyorum."(Ç9) }\end{array}$ \\
\hline \multirow{3}{*}{$\begin{array}{l}\text { EBA'da zorlanma } \\
\text { durumunda yardım } \\
\text { alınan kişiler }\end{array}$} & Abla & 3 & "Ablalarım."(Ç1) \\
\hline & Anne ve abla & 2 & "Annemden, ablamdan."(Ç2) \\
\hline & Anne, baba, teyze & 1 & \\
\hline \multirow{3}{*}{$\begin{array}{l}\text { EBA'dan Ders İşlerken } \\
\text { Hisler }\end{array}$} & Mutlu & 5 & "Yani arkadaşlarımı görüyorum ve \\
\hline & İyi, Güzel & 4 & $\begin{array}{l}\text { öğretmenlerimi görüyorum. Mutlu } \\
\text { oluyorum."(Ç10) }\end{array}$ \\
\hline & Heyecanlı & 3 & $\begin{array}{l}\text { Böyle bana çok heyecanlı bir } \\
\text { hissettiriyor." (Ç1) }\end{array}$ \\
\hline
\end{tabular}

Çalışmaya katılan öğrencilerin EBA'ya dair görüşleri incelendiğinde EBA'ya en fazla telefon ile girdikleri, EBA dışında derste kullandıkları kaynakları genelde bilmedikleri, EBA'yı fiziksel etkinlikler konusunda yetersiz gördükleri, derslerinde genelde zorlandıkları ve zorlandıklarında en fazla abalalarında yardım aldıkları bunların yanında genelde EBA'da ders işlerken kendilerini mutlu hissettiklerini ifade eden görüşler bildirmişlerdir. EBA ile ders yaparken arkadaşlarıyla yaptıkları koşma, oyun oynama gibi fiziksel etkinliklerin özlemi içinde olduklarını belirten öğrenciler herşeye rağmen sınıf̧̧a iletişimde olmaktan mutlu görünmektedir. Katılımc1 öğrencilerin EBA ders web sitesine ulaşmakta zorlandığını ifade eden öğrenci sayısı ile zorlanmadığını ifade eden öğrencilerin sayısı eşittir. 
Tablo 10. Öğrencilerin Uzaktan Eğitimle ilgili Diğer Görüşleri

\begin{tabular}{|c|c|c|c|}
\hline \multirow{5}{*}{$\begin{array}{l}\text { Öğrencilerin Ek Ödev } \\
\text { veya Görevlendirmeleri } \\
\text { İletirken Kullandığı } \\
\text { Araçlar }\end{array}$} & Temalar & $\mathbf{N}$ & Örnek ifade \\
\hline & Mesajlaşma uygulamaları & 8 & $\begin{array}{l}\text { "Telefondan.WhatsApp'tan } \\
\text { gönderiyorum."(C2) }\end{array}$ \\
\hline & & & $\begin{array}{l}\text { “Mesaj göndererek resim çekerek } \\
\text { iletiyorum whatsapp'tan..."(Ç3) }\end{array}$ \\
\hline & Ders esnasinda & 3 & $\begin{array}{l}\text { “Kameradan, öğretmenim bakabilir } \\
\text { misin?"(Ç5) }\end{array}$ \\
\hline & & & $\begin{array}{l}\text { "Canlı derste görüntümü açıр kitabımı } \\
\text { göstererek..."(Ç7) }\end{array}$ \\
\hline \multirow{7}{*}{$\begin{array}{l}\text { Yüz yüze Eğitim ile } \\
\text { Yapmak İstedikleri }\end{array}$} & Ders ile ilgili etkinlikler & 4 & "Saklambaç oynamak \\
\hline & Oyun oynamak & 6 & isterdim..."(Ç2) \\
\hline & & & " Onlarla oyun oynamak isterdim \\
\hline & & & $\begin{array}{l}\text { onlarla ders çalışmak isterdim } \\
\text { kitap okumak isterdim "(C3) }\end{array}$ \\
\hline & & & "Arkadaşlarımla oyun oynamak \\
\hline & Sözlü iletişim & 5 & isterdim, sohbet etmek isterdim. \\
\hline & & & $\begin{array}{l}\text { Oğretmenim ile de sohbet etmek } \\
\text { isterdim."(Ç8) "Öğretmenim sizi çok } \\
\text { özledim demek isterdim arkadaşlarıma } \\
\text { sıkıca sarılırdım. Sizi de çok özledim } \\
\text { derdim."(Ç1) }\end{array}$ \\
\hline \multirow{12}{*}{$\begin{array}{l}\text { Derste öğrenme } \\
\text { problemi yaşaması } \\
\text { halinde yaptıkları }\end{array}$} & İsteklendirme & 3 & "Böyle ben diyorum ki" ... sen \\
\hline & Destek & 3 & güçlüsün yapabilirsin "diyorum ve \\
\hline & Olumsuz duygular & 2 & yapıyorum çok kolay."(Ç1) \\
\hline & & & $\begin{array}{l}\text { “ Öğretmenim öğreneceksin } \\
\text { diyor.”(Ç6) }\end{array}$ \\
\hline & & & Matematikte azck zorlaniyorum. \\
\hline & & & Onda arkadaşlarımdan yardım \\
\hline & & & $\begin{array}{l}\text { istiyorum. Bazen de ögretmenimde } \\
\text { istiyorum."(Ç2) }\end{array}$ \\
\hline & Hiçbir şey & 2 & “ Konuyu anlamadı̆̆ım zaman \\
\hline & & & $\begin{array}{l}\text { anneme tekrardan anlatmasinı } \\
\text { istiyorum."(Ç3) }\end{array}$ \\
\hline & & & “Çözemediğim problem olduğun \\
\hline & & & olduğunda kötü hissediyorum. \\
\hline & & & $\begin{array}{l}\text { Ö̈̆retmenimin yanımda olmasımı } \\
\text { istiyorum."(Ç7) }\end{array}$ \\
\hline \multirow{8}{*}{$\begin{array}{l}\text { Öğretmenine ulaşma } \\
\text { yolları }\end{array}$} & Telefon & 4 & “Ö̈̆retmenim nasıl yapacağım \\
\hline & Mesaj(WhatsApp) & 4 & diyorum. Sesimi açıyorum öğretmenim \\
\hline & & & ne yapacağız hangi ders diyorum. \\
\hline & & & WhatsApp üzerinden."(Ç2 \\
\hline & & & Mesaj üzerinden yani WhatsApp'tan \\
\hline & Kendi Çabaları & 2 & $\begin{array}{l}\text { anlamsam annemden yardim } \\
\text { alıyorum."(C3) }\end{array}$ \\
\hline & & & “ Öğretmenime mesaj atıyoruz. \\
\hline & & & $\begin{array}{l}\text { Ö̈̆retmenim bizi (...)yani dersten attı } \\
\text { diye atabiliyorum."(Ç10) }\end{array}$ \\
\hline
\end{tabular}


Tablo 10'da öğrencilerin uzaktan eğitim süreci ile ilgili diğer görüşleri incelendiğinde öğrenciler; ek ödev veya görevlendirmeleri iletirken genelde mesajlaşma uygulamalarını kullandıkları, yüz yüze eğitime geçilmesi durumunda en çok yapmak istedikleri faaliyetin oyun oynamak olduğu, öğrenmede problem yaşanması halinde genelde isteklendirme ve destek aldıklarını, öğretmenlerine bu süreçte ulaşmak için telefon ve mesajı(WhatsApp) kullandıklarını ifade eden görüşler bildirmişlerdir.

\section{TARTIŞMA, SONUÇ ve ÖNERİLER}

EBA uygulamasının pandemi sürecindeki eğitim öğretim uygulamalarındaki etkisini görmeye yönelik yapılan araştırmada katılımcı sınıf öğretmenlerine anket ve ilkokul öğrencilerine yarı yapılandırılmış görüşme formu uygulanmıştır. Çalışmada öğretmenlerin EBA'ya yönelik olumlu ve olumsuz görüşleri farklı değişkenler açısından incelenirken; öğrencilerin derse katılma durumları, ek kaynak kullanımı, karşılaştıkları sorunlar gibi konularda görüşleri alınmıştır.

Araştırmaya katılan sınıf öğretmenleri ders süresinin yeterli oluğunu, içeriklerin öğrenci seviyesine uygun olduğunu düşünmesine rağmen öğretimde EBA'nın tek başına yeterli olmadığını düşünmektedir. Koçoğlu, Ulu Kalın, Tekdal ve Yiğen (2020) çalışmalarında farklı branşlardan öğretmenlerin çoğunun pandemi sürecindeki uzaktan eğitimi yeterli olduğu yönündeki görüşlerini belirtirken kaynak çeşidi bakımından yetersizlikleri de belirtmişlerdir. EBA içeriklerinin yetersiz olduğuna yönelik farklı çalışma bulguları bulunmaktadır (Arslan ve Kuzu, 2019; Doğan ve Koçak, 2020; Erensayın ve Güler, 2019; Kana ve Aydın, 2017; Kurtdede Fidan, Erbasan ve Kolsuz, 2016; Maden ve Önal, 2018).

Öğretmenlerin çoğu uzaktan eğitim döneminde öğrencilerine ulaşmakta zorluk çektiğini belirtmiştir. Öğrencilerinin çalışma ortamının uygun olmadığını düşünenler örneklemin yarısından fazladır. Öğretmenler, ödevlendirmelerde telefon ve whatsapp uygulamasını kullanmaktadır. Öğrencilerin internete erişimlerinin kısıtlı olması, dersleri takip için araç bulamamaları gibi durumlar çalışma ortamını bozan etkenler olabilir. Öğretmenler ödevlendirmede telefondan ve mesajlaşma uygulamalarından yararlandıklarını belirtmeleri uzaktan eğitimde teknolojiye bağlılığın ne kadar ön plana çıktığının göstermektedir. De Souza, Jardim, Junior, Marques, Lima ve Ramos (2020) Brezilya'da pandemi sürecinde uzaktan eğitimle ilgili yaptıkları araştırmada öğretmenlerin bilgi iletişim teknolojileri arasından whatsap kullanımında kendilerini daha yeterli bulduklarını ve uzaktan eğitimde sınıf kontrolünde, uzaktan öğrenme zorluklarında ve öğrenme ürünlerine ulaşmada desteğe daha fazla ihtiyaç duyduklarını belirtmektedir. Azhari ve Fajri (2021), Endonezya'da Covid-19 pandemi döneminde uzaktan eğitimde whatsapp uygulamasının en sık kullanıldığını, internet kesintilerinin olduğu, öğrencilerin bağımsız öğrenme yeteneklerinin olmadığını, aile desteğinin olmadığını ve öğretmenlerin pandemi öncesinde bilgi iletişim teknolojilerini kullanma deneyimlerinin olmadığını ve öğretmenlere teknik destek sağlanmadığını belirtmiştir. Fidan (2020) ve Doğan ve Koçak (2020) de öğretmenlerin uzaktan eğitim sürecinde alt yapı ve erişim sorunu yaşadıklarını belirtmiştir. TEDMEM (2020) raporuna göre EBA kullanamayan \%60 oranındaki öğrencinin öğretmenleri ile iletişim kuramadıkları, öğretmenden dönüt alamadıkları ortamda akademik olarak başarısız öğrencilerde EBA TV'nin yetersiz kalacağı belirtilmiştir. Uzaktan eğitim süreci içerisinde çoğu zaman en gelişmiş teknolojiyi kullanmak istenilen verimi elde etmek için yeterli gelen bir durum değildir (Tekinarslan, 2002). Yeterli verimi elde etmek için teknolojinin herkes tarafından da ulaşılır olması gerekir. Erturgut'un (2008) çalışmasında ulaşılabilir olmanın ve verimli dönütler sağlayarak beraber olmanın önemine değinmiştir. Araştırmada öğretmenlere göre 
velilerin meslek (eğitimleri) durumunun öğrencinin uzaktan eğitim sürecine etkisi olduğu; sorun yaşadıklarında en çok anne ve abla-ağabey gibi kardeşlerinden destek aldıklarını belirtilmiştir. Mesleklerin alınan eğitime göre şekillendiği düşünülürse eğitim düzeyi yüksek olan ailelerin çocukları ile daha fazla ilgilendikleri ve bu sorumluluğun büyük kısmını annelerin taşıdığ söylenebilir. Şenel ve Kutlu (2015) uzaktan eğitim sürecinde üniversite öğrencilerinin akademik başarısını yordayan faktörleri inceledikleri çalışmada aile ve çalışma ortamına ilişkin faktörlerinbirey sayısı, anne baba eğitim durumu, iş durumu- etkili olduğunu belirtmektedir. Annenin lise mezunu olması ve tam günlü bir işte çalışması akademik not ortalamaları varyansında \%2'lik katkı sağlamaktadır.

Sınıf öğretmenlerinin farklı değişkenlere göre görüşleri incelendiğinde; katılımcı öğretmenlerin neredeyse tamamı dersin süresini yeterli bulmuştur. Elde edilen bu bulgu Gözel ve Halat'1n(2010) çalışmasında belirttiği gibi sınıf öğretmenlerinin diğer branşlardaki öğretmenlere göre ders süresini yetiştirme konusunda daha başarılı olduğu sonucu ile de açılanabilir. Öğretmenlerin ders süresini yeterli bulma davranışları genellikle 41-50 yaş grubu öğretmenlerde görülmektedir. Bu durum ileri yaş öğretmenlerin zaman kontrolü konusunda daha planlı davrandıkları kanısına varılabilir. Ayrıca bu bulgudan yeni mesleğe başlayan öğretmenlerin genellikle zaman kontrolü konusunda problem yaşadıkları şeklinde de yorumlanabilir. Çalışmanın sonucunda ders süresinin yeterli bulma durumunun genellikle 1. sınıf öğretmenleri ve 13-20 yıl kıdemli öğretmenler tarafından ifade edildiği sonucuna varılmıştır. Bunun nedeni ilk okuma yazmayı öğretmek zor olsa da tecrübeyle ögrretmenlerin bu durumun üstesinden gelmesi ve alt kademlerde ders içeriğinin esnek yapıda olmasından kaynaklandığı söylenebilir. Clark'ın (2000) çalışmasında belirttiği gibi disiplin probleminin zaman kaybına sebep olmasından kaynaklı da olabilir. Çünkü öğrencilerin yaş aralıkları arttıkça disiplin sağlanması güçleşmektedir.

Öğretmenler genel olarak EBA uygulamasının içeriğini uygun bulduklarını bildirmişlerdir. Bu çalışmaya benzer şekilde Türker ve Güven'de (2016) çalışmalarında içeriğin öğrenci seviyesine uygun olduğu sonucuna varmıştır. Öğretmenlerden 1. sınıfı okutmakta olan öğretmenler genellikle içeriğin öğrenci seviyesine uygun olduğunu ifade ederken 4 . sinıf öğretmenleri bu görüşe en az katılan grup olmuştur. Bu durum ile EBA uygulamasının içeriğinin alt sınıf grupları için daha uygun hale getirildiği yorumu yapılabilir. Buna paralel olarak İskender (2016) ile Bahçeci ve Efe'nin(2018) çalışmasında da EBA uygulamasının sınıf seviyelerine uygun şekilde tasarlanması ve uyarlanması gerektiğine vurgu yapmıştır. Bunun yanı sıra içeriğin öğrencilerin seviyesine uygun olduğunu genelde 13-20 yıl kıdeme sahip 41-50 yaş grubu öğretmenler düşünürken; uygun olmadığını 1-5 yıl kıdeme sahip 22-30 yaş grubu öğretmenler ifade etmiştir. EBA platformunun içeriğinin eksik gören öğretmenler genelde başka kaynaklara da yönelmektedir. Saklan ve Ünal'ın(2019) çalışmasında da bazı öğretmenlerin yerli platformların yanına yabancılarını da tercih ettiğine değinmiştir.

EBA uygulamasının tek başına yeterli bulunma durumu incelendiğinde; örneklemin yarısından fazlası yeterli olmadığını ifade etmiştir. EBA'yı tek başına yeterli bulmayan öğretmenler genellikle 1-5 yıl kıdeme sahip öğretmenlerden oluştuğu ve dolayısı ile 22-30 yaş grubu öğretmenler tarafından ifade edildiği görülmüştür. Bu durumun nedeni olarak genç ve dinamik öğretmenlerin performanslarının daha fazla olduğu ve yeniliklere daha açık olması derslerinde ek kaynak uygulama kullanma ihtiyacını doğurmuş olabilir. Ayrıca bu öğretmenler tecrübe eksikliğinden dolayı nasıl online bir kaynağı verimli ve etkili kullanmakta güçlük çekmiş olabilirler. Buna paralel olarak Cemaloğlu ve Erdemoğlu Şahin'in (2007) çalışması da öğretmenlerin yaşları ilerledikçe duyarsızlaşma ve tükenmişliklerinin arttığı ve bu durumunda öğretmenlerin değişik 
performanslar göstermesine engel teşkil ettiği yönündedir. Bunun bir diğer nedeni öğretmenlerin çalıştıkları okulların uzaktan eğitimde farklı altyapıları kullanması olabilir.

Katılımcı sınıf öğretmenlerinin çok büyük bir kısmı ek kaynak kullandığını ifade etmiştir. Ek kaynak kullandığını ifade eden öğretmenlerin çoğunluğu 21- 40 yıl kıdeme sahip öğretmenler tarafından dile getirilmiştir. Bunun nedeni bu yaş grubu öğretmenlerin öğrencilerin anlama düzeylerini tahmin ederek öğrenmeyi destekleme çabası ile açıklanabilir. Yine internete ulaşım sorunu olan öğrenciler için ek kaynakları alternatif öğretim materyali olarak düşünmeleri olabilir. Türker ve Güven'in (2016) çalışmasında belirttiği gibi ă̆ yetersizliğinden kaynaklı ek kaynak kullanımına ihtiyaç duyuyor olabilir. Öğretmenlerin ek kaynak tercih etmelerinin sebebi Gömleksiz ve Koç Deniz'in (2018) çalışmasında da belirttiği gibi EBA içeriğinde daha değişik ve fazla soru olmamasından dolayı olabilir. Branekova'nın (2020) çalışmasında da belirttiği gibi uygun öğrenme ortamlarında öğretmenler farklı platformları kullanabilmelidir.

Öğretmenler hizmet bölgeleri ile uzaktan eğitim sürecine ilişkin görüşleri incelendiğinde; öğretmenlerin genel olarak öğrencilerine ulaşmakta zorlandığını bildirmiştir. Öğrencilerine ulaşmakta zorlandığını ifade eden öğretmenlerin genellikle 1. bölgede görev yapmaktadır. Katılımcı öğretmenlerin büyük çoğunluğu öğrencilerinin çalışma ortamının uygun olmadığını belirtmiştir. Öğrencilerinin çalışma ortamını uygun bulmayan öğretmenlerin büyük bir çoğunluğu da yine 1. bölgede görev yapmakta olan öğretmenlerdir. Bu durum Zhang, Wang, Yang ve Wang'in (2020) çalışmasında da belirttiği gibi evlerdeki karmaşık ortamlar olabileceği bulgusu ile örtüşmektedir. Buna yönelik olarak velilerin çalışma ortamını uygun hale getirmesi önemlidir. Hizmet bölgelerine göre velilerin mesleklerinin uzaktan eğitim sürecine etkisi incelendiğinde örneklemin neredeyse hepsi velilerin mesleklerinin süreci etkilediğini ifade ederken çoğunluk yine 1. bölgede görev yapan öğretmenlerdedir. Hizmet bölgesi coğrafi, ekonomik ve sosyal yönden gelişmişlik düzeyini belirtmektedir. Örneklemi oluşturan öğretmenlerin büyük kısmı (202 kişi) bu bölgede çalışmaktadır. Hizmet bölgesine göre uzaktan eğitime yönelik görüşlerin ilişkisi anlamlı bulunmamıştır. Aynı şekilde okutulan sınıf düzeyi, mesleki kıdem ve yaş değişkenleri ile EBA hakkındaki görüşlerin ilişkisi anlamlı bulunmamıştır.

Katılımcı öğrenciler EBA uygulamasının içeriğine ulaşmak için en çok telefon aracını kullandıklarını ifade etmişlerdir. Bunun nedeni bu yaş grubundaki çocukların ailelerinin gözetiminde telefonlarını kullanıyor olmaları olabilir. Ayrıca evinde kişisel bilgisayar veya tablete sahip çocuk sayısının az olması da diğer bir neden olabilir. Çalışmaya katılan çocukların yarısı EBA ders Web sitesine ulaşmakta zorlandığını ifade etmiştir. Buna paralel olarak Tüysüz ve Çümen'in (2016) ve Alaybay'in (2015) çalışmasında ortaokul öğrencileri EBA Ders Web sitesine ulaşmak da güçlük çektiğini ifade ederken Bahçeci ve Efe (2018) lise öğrencilerinin EBA uygulamasına kolaylıkla ulaştığını ifade etmiştir. Bu çalışmaların ışığında öğrencilerin EBA web sitesine ulaşmakta zorlanma durumunun nedenini yaşlarının küçük olması yorumu yapılabilir. Ayrıca telefonla uzaktan eğitime katılıp canlı dersleri takip etmenin zorluğu Maniar, Bennett, Hand ve Allan, (2008) tarafından da belirtilen bir durumdur. Araştırmanın sonuçlarından bir diğerine göre de öğrenciler genelde EBA dışında hangi kaynağı kullandıklarını bilmediklerini ifade etmişlerdir. Bunun nedeni öğrencilerin yaş grubunun küçük olması ve bu gibi kavramsal terimleri akıllarında tutamıyor olmaları olabilir. Çocuklar EBA'nın fiziksel etkinlikler yönünden yetersiz kaldığını ifade etmiştir. Bunun nedeni çocukların sosyal ortamlardan uzak kalması sonucu fiziksel etkinlikler ile enerjilerini boşaltma ihtiyacı duymaları olabilir. Arkadaşlarıyla oynamak, koşmak, öğretmeniyle konuşmak çocuklar için bu dönemde bir ihtiyaç ve özlem halini almıştır. Fiziksel etkinliklerle enerjisini atamayan çocuklar ev içinde ders çalışmak dışında da televizyon, 
tablet ve telefonla vakit geçirmektedir. Bu durumun ruhsal ve fizyolojik zararları ilerleyen zamanlarda çocuklarda bir takım sorunlar ortaya çıkartabilir. Bu nedenle ailelerin okulun sağladığı sosyalleşme ve fiziksel etkinlik imkânını çocuklarına sağlayacak düzenlemeleri yapmaları gerekmektedir.

Katılımcı ilkokul öğrencileri genel olarak ödevlendirmelerde zorlandığını ve bu gibi durumda genellikle anne ve büyük kardeşlerinden yardım aldıklarını belirtmiştir. Buna yönelik olarak aile içi bireylerin genelinin çocuklar üzerinde ilgi ve desteklerini hissettirecek şekilde davranmaları gerektiği yorumu getirilebilir. $\mathrm{Bu}$ araştırmadaki önemli bir sonuç annelerin uzaktan eğitim sürecinde çocuklarına eğitim desteğinde ilk sırayı almasıdır. Öğretmenlerin ankete verdikleri cevaplar da annelerin derslerde yardım konusunda ilk sırada olduğu yönündedir. Fidan (2020) uzaktan eğitim sürecine velilerin yeterince destek vermediği yönünde öğretmen görüşleri bildirmektedir. Pandemi sürecinde okuldan eve aktarılan eğitim sürecinde annenin sorumlulukları arasına çocuğun derslerini birebir takip etmek ve sorun çözmek de eklenmiştir. Bu süreçte çalışan annelerin esnek çalışma saatleri ile çocuklarının yanında olabilmeleri eğitimlerini desteklemek adına büyük bir fırsat olmuştur. Öğrenciler genel olarak EBA'da dersleri takip ederken veya işlerken kendilerinin mutlu hissettiklerini ifade etmiştir. Bunun nedeni uzaktan eğitimin interaktif bir şekilde öğrenciyi dâhil etmeye yönelik çok fazla materyal barındırması olabilir. Yine ekranda da olsa arkadaşlarıyla ve öğretmeniyle görüşmek çocukları mutlu etmektedir. Çalışmaya paralel olarak Çetin ve Günay'ın (2011) EBA içeriğinde oyun, video, interaktif etkinliklerin çok fazla yer almasının öğrencilerin bu platformdayken kendilerini mutlu hissetmesine sebep olduğu bulgusu ile örtüşmektedir.

Öğrenciler kendilerine verilen ödev ve görevlendirmeleri mesajlaşma uygulamaları ile öğretmenlerine gönderdiğini ifade etmiştir. Bu durumun nedeni öğretmenlerin kâğıt kalem üzerinden etkinlik ödevlerine resim aracılığı ile ulaşma talebi olabilir. Öğrenciler yüz yüze eğitime geçtiklerinde oyun oynamak istediğini belirmiş. Bu durumun nedeni öğrencilerinin yaş grupları ile açıklanabileceği gibi sürecin öğrencileri sosyal hayattan soyutlaması ile de açılanabilir. Öğrenciler derste öğrenme problemi olması halinde destek ve motivasyon ile başa çıtıklarını ifade etmiştir. Zhou, Li, Wu ve Zhou (2020) Covid-19 sürecinde uzaktan eğitimle öğrencilerin daha özerk ve kişiselleştirilmiş bir öğrenme deneyimine sahip olmaları, öğrencilerin öğrenme sürecini kavramalarına ve kendi bilgi ve yetenek seviyelerine göre öğrenme ortamını seçmelerine olanak tanıdığını belirtmektedir. Bazı öğrenciler güçlükler karşısında daha azimli olurken bazları pes edebilir. Buna yönelik olarak literatürde yetersizliği bulunan öğrencilere destek verilmesi gerektiğine değinilmiştir (Özer,2020). Öğrencilerden elde edilen bulgular doğrultusunda öğrencileri bağlantı kopması durumunda en fazla WhatsApp'dan öğretmenlere ulaştığını göstermektedir. Uzaktan eğitim sürecinde öğretmenlerin her an ulaşılabilir olması ve velinin de işbirliğine ılımlı bakması gerekmektedir. Duban ve Şen'e (2020) göre öğretmen sürekli olarak öğrencileri ile diğer sosyal medya araçları ile iletişimde olmalıdır. Buna paralel olarak Aldemir ve Avşar (2020) çalışmalarında pandemi dolayısı ile insanların zamanlarının büyük bir kısmını teknolojik araçlar ile geçireceğini ve birçok çeşitli aracı eğitimlerine devam etmek için kullanacağını görüşü ile örtüşmektedir.

Araştırma sonucunda aşağıdaki önerilerde bulunulmuştur:

- Bu çalışma sadece sınıf öğretmenleri ile yapılmıştır. Çalışmanın örneklemini genişletip tüm eğitim kademelerinde EBA kullanan öğretmenler ile çalışmalar yapılabilir. 
- Öğretmenlerin EBA'yı yetersiz buldukları yönler detaylı olarak incelenerek iyileştirme çalışmaları yapılabilir.

- Pandemide EBA uygulamasının eğitim sürecindeki etkileri veya eksik yanlarına yönelik velilerin görüşleri araştırılabilir.

- Pandemi sürecinde uzaktan eğitimde öğretmenlerin ve öğrencilerin duyuşsal özelliklerini tespit amacıyla ölçek geliştirme çalışmaları yapılabilir.

\section{KAYNAKLAR}

Alaybay, A. (2015). Ortaöğretim öğretmenlerinin ve öğrencilerinin EBA (ĕğitimde bilişim ağı) kullanımına ilişkin görüşleri üzerine bir araştırma. (Yayımlanmamış yüksek lisans tezi). İstanbul Aydın Üniversitesi Sosyal Bilimler Enstitüsü, İstanbul.

Aldemir, C. \& Avşar, M. N. (2020). Pandemi döneminde dijital vatandaşlık uygulamaları. Avrasya Sosyal ve Ekonomi Araştırmaları Dergisi, 5(2),148-169.

Alkan, C. (2011). Ĕğitim Teknolojisi. Ankara: Anı Yayıncılık.

Ateş, M., Çerçi, A. \& Derman, S. (2015). Eğitim bilişim ağında yer alan Türkçe dersi videoları üzerine bir inceleme. Sakarya Üniversitesi Fakültesi Dergisi, 5(3), 105-117.

Ayan,E.(2018). Öğretmenlerin eğitim bilişim ă̆g içeriğini kullanma ve e-içerik geliştirme durumlarının incelenmesi. (Yayımlanmamış yüksek lisans tezi). Hacettepe Üniversitesi, Sosyal Bilimler Enstitüsü, Ankara.

Azhari, B. \& Fajri, I. (2021). Distance learning during the COVID-19 pandemic: School closure in Indonesia. International Journal of Mathematical Education in Science and Technology. DOI: 10.1080/0020739X.2021.1875072

Bahçeci, F. \& Efe B. (2018). Lise öğrencilerinin Eğitim Bilişim A $\breve{g}$ (EBA) sitesine yönelik görüşlerinin değerlendirilmesi. Kuramsal Eğitimbilim Dergisi, 11(4), 676-692.

Bozkurt, A. (2017). Türkiye'de uzaktan eğitimin dünü, bugünü ve yarını. Açı öğretim Uygulamaları Ve Araştırmaları Dergisi, 3(2), 85-124.

Branekova, D.(2020). The successful model of distance learning. Trakia Journal of Sciences. 18(1), 275-284.

Cemaloğlu, N. \& Erdemoğlu Şahin, D. (2007). Öğretmenlerin mesleki tükenmişlik düzeylerinin farklı değişkenlere göre incelenmesi. Kastamonu Eğitim Dergisi, 15(2) , 463-484 .

Clark, R. E. (2000). Evaluating distance education: Strategies and cautions. In Simonson M., \& Schlosser C. (Eds). Quarterly review of distance education (pp. 3-16). North Miami Beach, FL: Information Age Publishing.

Creswell, J. W. \& Clark, V. L. P. (2018). Karma Yöntem Araştırmaları: Tasarımı ve Yürütülmesi (Çev. Ed. Y. Dede ve S.B. Demir). Ankara: Anı Yayıncılık.

Çepni, S. (2018). Araştırma ve proje çalışmalarına giriş, 8. Baskı, Yazarın Kendi Yayını, Trabzon.

Çetin, O ve Günay, Y. (2011). Fen eğitimine yönelik örnek bir web tabanlı öğretim materyalinin hazırlanması ve bu materyalin öğretmen öğrenci görüşleri doğrultusunda değerlendirilmesi. Ahi Evran Üniversitesi Ĕ̆itim Fakültesi Dergisi, 12(2), 175-202.

De Souza, G.H., Jardim, W.S., Junior, R.L., Marques, Y.B., Lima, N.C. \& Ramos, R.S. (2020). Brazilian students' expectations regarding distance learning and remote classes during the COVID-19 pandemic. Educational Sciences: Theory E Practıce, 20(4), 64-80.

Demirarslan, Y. \& Usluel, Y.K.(2005). Bilgi iletişim teknolojilerinin öğrenme öğretme sürecine entegrasyonun da öğretmenlerin durumu. Turkish Journal of Educational Technology, 4(3), 109113. 
Doğan, S. \& Koçak, E.(2020). EBA sistemi bağlamında uzaktan eğitim faaliyetleri üzerine bir inceleme. Journal of Economics and Social Research, 7(14), 110-124.

Duban, N. Şen, F. G. (2020). Sınıf öğretmeni adaylarının COVID-19 pandemi sürecine ilişkin görüşleri. Turkish Studies, 15(4), 357-376.

Erensayın, E. \&Güler, Ç. (2019). Çevrimiçi ders materyallerinin değerlendirilmesi: EBA ders örneği. Hacettepe Üniversitesi Ĕ̆itim Fakültesi Dergisi, 36(1), 74-89.

Erturgut, R. (2008). İnternet temelli uzaktan eğitimin örgütsel, sosyal pedagojik ve teknolojik bileşenleri. Bilim Teknolojileri Dergisi, 1(2), 79-85.

Fidan, M. (2020). Covid-19 belirsizliğinde eğitim: ilkokulda zorunlu uzaktan eğitime ilişkin ögretmen görüsşleri. Uşak Üniversitesi Ĕ̆gitim Araştırmaları Dergisi, 6(2). 24-43.

Gezer, M. \& Durdu, L. (2020). Eğitim Bilişim Ağ1 (EBA) ile ilgili tezlerin sistematik analizi. Başkent University Journal Of Education, 7(2), 393-408

Gömleksiz, M.N. \& Deniz,H.K.(2019). Eğitim bilişim ağ1 (EBA) ders Web sitesine ilişkin matematik öğretmenlerinin görüşleri. Türkish Studies,14(3),431-446.

Gözel, E. \& Halat E. (2010). İlköğretim okulu öğretmenleri ve zaman yönetimi. Pamukkale Üniversitesi Sosyal Bilimler Enstitüsü Dergisi, 6, 73-89.

Hobson, T.D. \& Puruhito, K.K. (2018). Goingthedistance: Online course performance and motivation of distance-learning students. Online Learning, 22(4), 129-140.

İskender, H. (2016). Eğitim Bilişim Ağı'nda bulunan 7. sınıf Türkçe dersi videolarının ilköğretim Türkçe dersi (6, 7, 8. sinıflar) öğretim programıla uyumu. Adıyaman Üniversitesi Sosyal Bilimler Enstitüsü Dergisi, 8(24), 1043-1068.

Kana, F. \& Aydın, V. (2017). Ortaokul öğretmenleri ve öğrencilerinin eğitim bilişim ağı hakkında görüşleri. International Journal of Social Humanities Sciences Research, 4(13),1494-1504

Karaman, D. v\& Aydoğmuş,U.(2018). Üniversite öğrencilerinin Yaşam Boyu Öğrenme Eğilimleri Uşak Üniversitesi Eşme MYO'da bir uygulama. Nevşehir Hacıbektaş Üniversitesi SBE Dergisi,(1),23-44.

Kılıç Çakmak, E., Özüdoğru, G., Bozkurt, Ş. B., Ülker, Ü., Özgül Ünsal, N., Boz, K., Bozkurt, Ö. F., Ergül Sönmez, E., Baştemur Kaya, C., Karaca, C., Bahadır, H., \& Üstün Gül, H. (2016). 2014 yılında eğitim teknolojileri alanındaki yayımlanan makalelerin incelenmesi. Eğitim Teknolojisi Kuram ve Uygulama, 6(1), 80-108.

Koçoğlu, E., Ulu Kalın, Ö., Tekdal, D. \& Yiğen, V. (2020). Covid-19 pandemi sürecinde Türkiye' deki eğitime bakış. International Social Sciences Studies Journal, 6(65), 2956-2966.

Köklü, N.(1994). Örnek olay çalışma metotları. Ankara Üniversitesi EBF Dergisi, 27(2),771-779.

Kurtdede Fidan, N., Erbasan, Ö. \& Kolsuz, S. (2016). Sınıf öğretmenlerinin eğitim bilişim ağı'ndan (eba) yararlanmaya ilişkin görüşleri. Uluslararası Sosyal Araştırmalar Dergisi, 9(45), 626-637.

Maden, S. \& Önal, A. (2018). Elektronik bilişim ağındaki ortaokul Türkçe dersi içeriklerinin kullanımı üzerine bir araştırma. Dil Ĕ̆gitimi ve Araştırmaları Dergisi, 4(2), 101-121.

Makatouni, A. (2002). What motivates consumers to buy organic food in the UK? Results from a qualitative study. British Food Journal, 104(3/4/5), 345-352.

Maniar, N., Bennett, E., Hand, S., ve Allan, G. (2008). The effect of mobile phone screen size on video based learning. Journal of Software, 3(4), 51-61.

Marton, F. (1986). Phenomenography: A research approach to investigating different understanding of reality. Journal of Tought, 21(3), 28-49.

Mazlum,M.M. ve Atalay, A.(2017). Sosyal bilimlerde araştırma yönteminin belirlenmesi. Educational and Social Science Journal, 4(16), 1-21.

Özer, M. (2020). Türkiye'de COVİD-19 salgını sürecinde Milli Eğitim Bakanlığı tarafından atılan 
politika adımları. Kastamonu Education Journal, 28(3), 1124-1129.

Pala, F, Arslan, H, \& Özdinç, F. (2017). Eğitim Bilişim Ağ̀ web sitesinin otantik görevler ve göz izleme ile kullanılabilirliğinin incelenmesi. Ihlara Ĕ̆gitim Araştırmaları Dergisi, 2(1), 24- 38

Patton,M. Q.(1987). How to use qualitative methods in evaluation. Newbury Park, CA: Sage.

Saklan, H. \& Ünal, C. (2019). Dijital eğitim platformları arasında eba'nın yeri ile ilgili fen bilimleri öğretmenlerinin görüşleri. Ondokuz Mayıs Üniversitesi Eğitim Fakültesi Dergisi, 38(1), 19-34.

Sönmez, M., Yıldırım, K. \& Çetinkaya, F. Ç. (2020). Yeni tip Koronavirüs (SARS-CoV2) salgınına bağlı uzaktan eğitim sürecinin sınıf öğretmenlerinin görüşleriyle değerlendirilmesi. Turkish Studies, 15(6), 855-875.

Sönmez, V. \& Alacapınar, F.G.(2014).Örneklendirilmiş bilimsel araştırma yöntemleri. Ankara: Anı Yayıncilik.

Şenel, S. \& Kutlu Ö. (2015). Ankara üniversitesi uzaktan eğitim programına katılan öğrencilerin akademik başarılarını yordayan faktörler. Eğitimde ve Psikolojide Ölçme ve Değerlendirme Dergisi, 6(2), 177-193

TEDMEM. (2020). COVID-19 sürecinde eğitim uzaktan öğrenme, sorunlar ve çözüm önerileri. (TEDMEM Analiz Serisi 7). Ankara: Türk Eğitim Derneği Yayınları.

Tekinarslan, E. (2002). Distance education: Technologies, 1ssues and considerations. Abant İzet Baysal Üniversitesi Eğitim Fakültesi Dergisi, 2(3), 65-73.

Tınmaz, H. (2013). Öğretim teknolojilerinin temelleri: Teoriler, araştırmalar, eğilimler.(Ed. Kürşat Çğıltay ve Yüksel Göktaş). Ankara: Pegem Akademi Yayınları.

Tutar, M. (2015). Eğitim Bilişim Ağı (EBA) sitesine yönelik olarak öğretmenlerin görüşlerinin değerlendirilmesi. (Yayımlanmamış yüksek lisans tezi). Karadeniz Teknik Üniversitesi Eğitim Bilimleri Enstitüsü, Trabzon.

Türker,A. \& Güven, C. (2016). Lise öğretmenlerinin eğitim bilişim ağı (EBA) projesinden yararlanma düzeyleri ve proje ile ilgili görüşleri. Eğitim ve Öğretim Araştırmaları Dergisi, 5(1), 244-254.

Tüysüz, C. \& Çümen,V. (2016). EBA ders Web sitesine ilişkin ortaokul öğrencilerinin görüşleri. Uşak Üniversitesi SBE Dergisi, 9 (27/3), 278-296.

UNESCO (2020, March 27). Teacher Task Force calls to support 63 million teachers touched by the COVID-19 crisis. UNESCO. Retrieved from "https://en.unesco.org/news/teacher-task-forcecalls-support-63-million-teachers-touched-covid-19-crisis"

Üstün, Ç. \& Özçiftçi, S. (2020). COVID-19 pandemisinin sosyal yaşam ve etik düzlem üzerine etkileri: Bir değerlendirme çalışması. Anadolu Kliniği Tıp Bilimleri Dergisi, 25(1), 142-153.

Viner, R., Russell, S.J, Croker, H., Packer, J., Ward, J., Stansfield, C. \& Booy, R. (2020). School clouse and management practices during coronovirus outbreaks including COVID-19: A rapid systematic review. The Lancet Child \& Adolescent Health, 4, 397-404.

Yıldırım, A. \& Şimşek, H. (2018). Sosyal Bilimlerde Nitel Araştırma Yöntemleri. Ankara: Seçkin Yayıncilik.

Zhang, W., Wang, Y., Yang, L., \& Wang, C. (2020). Suspending clases without stopping learning: China's education emergency managament policy in the COVID-19 outbreak. Journal of Risk and Financial Management, 13(3), 55-61.

Zhou, L., Li, F., Shanshan Wu, S. \& Zhou, M. (2020). "School's out, but class's on", the largest online education in the world today: Taking China's practical exploration during the COVID-19 epidemic prevention and control as an example. Best Evid Chin Edu, 4(2), 501-519. 